\title{
Effect of deformation on dehydrogenation mechanisms of crumpled graphene: molecular dynamics simulation
}

\author{
K. A. Krylova ${ }^{\dagger, 1}$, J. A. Baimova ${ }^{1,2}$, R. R. Mulyukov ${ }^{1,2}$ \\ †bukreevakarina@gmail.com \\ ${ }^{1}$ Institute for Metals Superplasticity Problems, RAS, 39 Khalturin St., Ufa, 450001, Russia \\ ${ }^{2}$ Bashkir State University, 32 Zaki Validi St., 450076, Ufa, Russia
}

\begin{abstract}
In this work, the effect of hydrostatic compression on dehydrogenation of crumpled graphene is investigated using molecular dynamics simulation. Crumpled graphene is a carbon structure composed of a large number of graphene flakes interacted by van der Waals forces. These ultralight materials have unique mechanical properties and can be used in various applications, for example, in hydrogen technologies. One of the important issues in the study of carbon structures is the search for the new materials for hydrogen storage and transportation. In the present work, it is shown that pores of crumpled graphene can be used as the caves for the storage of hydrogen atoms and molecules, and hydrostatic compression is an effective way of keeping hydrogen inside the caves. Based on the analysis of changes in the capacity of hydrogen absorption, it is found that the application of deformation leads to a significant improvement in the sorption characteristics of crumpled graphene. At the same time, hydrostatic compression of crumpled graphene leads to an increase in volumetric hydrogen capacity. It has been established that, with an increase in the degree of compression, the number of hydrogen atoms leaving the pores of crumpled graphene decreases after exposure at $300 \mathrm{~K}$. It is expected that the subsequent heating of the structure will lead to the release of hydrogen due to the opening of graphene flakes and an increase in thermal fluctuation oscillations of atoms, which is important for the dehydrogenation process.
\end{abstract}

Keywords: crumpled graphene, hydrogen technology, hydrogen storage, molecular dynamics.

УДК: 539.2

\section{Влияние деформации на процесс разводораживания ском- канного графена: молекулярно-динамическое моделирование}

\author{
Крылова К. А., ${ }^{\dagger,}$ Баимова Ю. А., ${ }^{1,2}$ Мулюков Р. Р. ${ }^{1,2}$ \\ †bukreevakarina@gmail.com \\ ${ }^{1}$ Институт проблем сверхпластичности металлов РАН, ул. Халтурина, 39, Уфа, 450001, Россия \\ ${ }^{2}$ Башкирский государственный университет, ул. Заки Валиди, 32, Уфа, 450076, Россия
}

В данной работе методом молекулярно-динамического моделирования исследуется влияние сжимающей гидростатической деформации на процесс разводораживания скомканного графена. Скомканный графен представляет собой углеродную структуру, состоящую из большого количества графеновых чешуек, связанных между собой силами Ван-дер-Ваальса. Эти структуры обладают уникальными механическими свойствами и являются сверхлегкими материалами, поэтому могут найти применение в различных отраслях промышленности, например, в водородной энергетике. Одним из важных направлений в исследовании углеродных структур является создание новых материалов для хранения и транспортировки водорода. В представленной работе показано, что поры скомканного графена могут использоваться как емкости для хранения атомов водорода, при этом гидростатическое сжатие является эффективным способом удержания водорода внутри структуры. На основе анализа изменения плотности наводораживания установлено, что применение деформации ведет к существенному улучшению сорбционных характеристик структуры. При этом гидростатическое сжатие скомканного графена приводит к увеличению объемной плотности наводораживания. Установлено, что с ростом степени сжатия структуры количество атомов водорода, покинувших 
поры скомканного графена в процессе выдержки при температуре $300 \mathrm{~K}$, заметно уменьшается. При этом увеличение степени сжатия больше 25\% не рассматривается, поскольку при этих деформациях могут появляться расчетные ошибки.. Ожидается, что последующий нагрев структуры приведет к высвобождению водорода за счет раскрытия чешуек графена и возрастания термофлуктуационных колебаний атомов.

Ключевые слова: скомканный графен, водородная энергетика, хранение водорода, молекулярная динамика.

\section{Introduction}

The search of new carbon structures has not ceased over the past decades due to its unique properties found both in theoretical and experimental studies [1-13]. To date, carbon aerogels [1], crumpled graphene [2-4], pillared graphene [5,6], moiré graphene bilayers [7], diamondlike carbon phases [9-13] and many others have been experimentally synthesized or theoretically studied. These ultra-light materials have unique mechanical characteristics and good conductive properties, and, therefore, can be used in various industries, for example, energy storage, nanoelectronics, photovoltaics, and sensor devices. One of the important issues is the use of new carbon materials for hydrogen transportation and storage. The advantages of carbon nanostrucutres are a large specific surface area, low density compared with intermetallic compounds, chemical inertness, to name a few. Today, different carbon structures were considered for reversible hydrogen sorption [14-20]. Various systems are considered as potential hydrogen sorbents, both traditional (activated carbon and graphites) and new (porous carbon, nanocarbon fibers and tubes). A special characteristic of such materials is the rapid kinetics and complete reversibility of hydrogen adsorption.

Crumpled graphene is a carbon structure consisting of graphene flakes interacted by van der Waals forces. A simple and green way to synthesize this nanomaterial with an ultrahigh specific surface $\left(3523 \mathrm{~m}^{2} / \mathrm{g}\right)$ and high conductivity was proposed in [2]. Analysis of the structure showed that such a material consists of many defective/crumpled graphene flakes several nanometers in size. It was established that carbon atoms with $s p^{2}$ hybridization prevail in this structure. It is well known that the maximum measured hydrogen capacity of graphene is $2 \%$ wt., which is much lower than the minimum required value of $5-6 \%$ wt. Therefore, in order to increase the mass of hydrogen accumulated in the structure, it is necessary to use not chemical, but physical methods of storing hydrogen in carbon material. For example in [21] a way to create a graphene box filled with molecular hydrogen was proposed. Crumpled graphene is a very promising material for hydrogen energy because pores of the structure can be natural sources of hydrogen accumulation.

Therefore, it is important to investigate ways of storage and transportation of hydrogen in crumpled graphene. This paper is devoted to the atomistic modeling of dehydrogenation mechanisms of crumpled graphene, depending on the degree of compressive deformation.

\section{Simulation details}

Molecular dynamics, which well reproduces the properties of the carbon structures and studies structural changes during deformation, as well as estimating the characteristics of hydrogenated graphene is used for the study of crumpled graphene and the effect of deformation on dehydrogenation mechanisms. All the simulations are carried out using the freely distributed simulation package LAMMPS with the interatomic interactions potential AIREBO [22], which was shown to reproduces well the properties of various hydrocarbon structures. In particular, it was used to study discrete breathers in graphane [23-25], mechanical properties of hydrogenated graphene [26,27], various structural configurations of hydrogenated graphene [28 - 30], and others. Analysis of the results is carried out using home-made software packages.

The schematic of generation of the initial structure is shown in Fig. 1a, b. A single structural element - graphene flake $\left(N_{\mathrm{C}}=616\right)$ (Fig. 1b) was obtained by cutting atomic

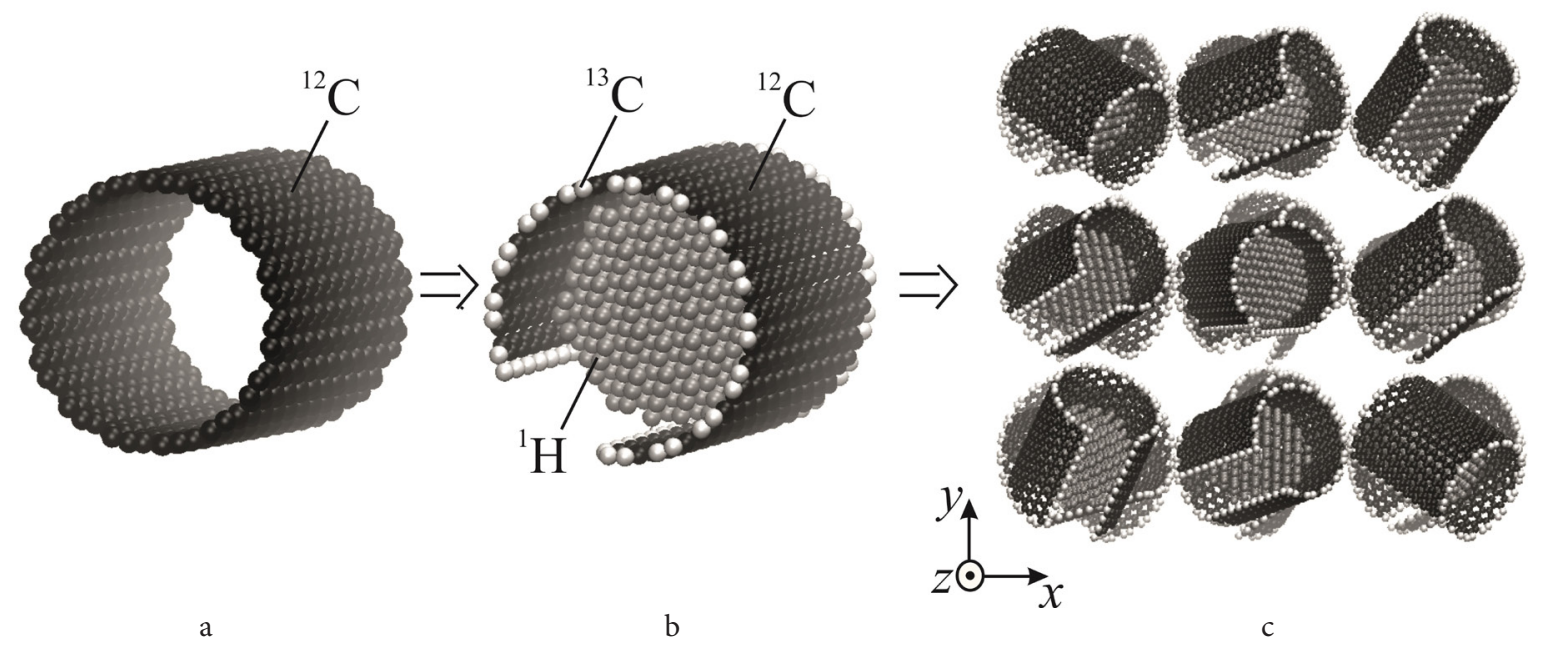

Fig. 1. Schematic of how the initial structure of crumpled graphene is obtained: carbon nanotube $(15,15) 2.5 \mathrm{~nm}$ long (a); graphene flake with hydrogen atoms in the pore (b); crumpled graphene, consisting of randomly oriented graphene flakes, repeated along three $x, y, z$ coordinate axes (c). Hydrogen atoms ${ }^{1} \mathrm{H}$ are gray, carbon atoms ${ }^{12} \mathrm{C}$ are black, and edge carbon atoms ${ }^{13} \mathrm{C}$ with higher molar mass are white. 
rows from a $2.5 \mathrm{~nm}$ long carbon nanotube $(15,15)$ (Fig. 1a). A similar method of generation of the initial structures was used earlier in modeling crumpled graphene [31-33]. The chemical reactivity of the carbon atoms localized on a graphene flake edge differs from the relative inertness of the basal plane [34]. Broken $\sigma$-bonds at the edges develop radical groups with accessible and highly active electrons. One of the simplest ways to modify the edge atom and to take into account the chemical activity of the edge atoms is to add hydrogen atom and create $\mathrm{CH}$ group [35]. Thus, atoms along the edges of a graphene flake are considered as $\mathrm{CH}$ group with the mass of $13 m_{p}$, while carbon atoms in a basal plane have a mass of $12 m_{p}$, where $m_{p}=1.6603 \times 10^{-27} \mathrm{~kg}$. Hydrogen atoms $\left(N_{\mathrm{H}}=371\right)$ are placed inside the cave of the flake, after which it was transmitted along the three $x, y, z$ coordinate axes so as to obtain a $3 \times 3 \times 3$ unit cell (Fig. 1c). In total, the simulation cell contains $N=26649$ with $N_{\mathrm{C}}=16335$ carbon atoms and $N_{\mathrm{H}}=10314$ hydrogen atoms. The orientation of each graphene flake inside the simulation cell was set randomly (see Fig. 1c). In Fig. 1, the ${ }^{1} \mathrm{H}$ hydrogen atoms are represented in gray, the ${ }^{12} \mathrm{C}$ carbon atoms are black, and the edge carbon atoms with a higher molar mass are shown in white ${ }^{13} \mathrm{C}$.

It should be noted that an increase in the structure does not lead to a significant change in the simulation results. In the presented model, the simulation cell is located in a certain free space in all three directions $x, y, z$, which allowed the hydrogen atoms to move out of the crumpled graphene and freely move inside the cell.

The initial structure is relaxed to the state with the minimum potential energy. The initial density of the structure without hydrogen is $\rho_{0}(C)=0.04182 \mathrm{~g} / \mathrm{cm}^{3}$, and the specific surface area of crumpled graphene is $11189 \mathrm{~m}^{2} / \mathrm{g}$. The initial gravimetric capacity of hydrogen, which is defined as the ratio of the mass of all hydrogen to the mass of the entire system, is $\rho_{g 0}=34.48 \% \mathrm{wt}$., The initial volumetric capacity of accumulated hydrogen, which is defined as the mass of accumulated hydrogen per unit volume, is $\rho_{V 0}=0.01127 \mathrm{~g} / \mathrm{cm}^{3}$.

The computational cell is subjected to hydrostatic compression $\left(\varepsilon_{x}=\varepsilon_{y}=\varepsilon_{z}=\varepsilon\right)$ at a temperature close to $0 \mathrm{~K}$, where $\varepsilon<0$ is a deformation parameter monotonically increasing with a rate of $0.1 \mathrm{ps}^{-1}$. After applying several different values of compressive strain $(\varepsilon=5,10,15,20,25 \%)$, the structure is maintained at a temperature of $300 \mathrm{~K}$ using a Nose-Hoover thermostat to follow the process of graphene dehidrogination at each value of the chosen strain. The exposure time is $2 \mathrm{ps}$, an increase of which did not lead to significant changes in the results obtained.

\section{Results and discussion}

Fig. 2 shows changing of number of hydrogen atoms in crumpled graphene as the function of strain $\varepsilon$ after exposure at $300 \mathrm{~K}$. It can be seen that with the increase of deformation value the number of hydrogen atoms monotonously decreases from $\sim 2500$ to $\sim 600$ atoms. Value of the absorbed hydrogen does not changing during exposure (curve with the blue squares in Fig. 2) which can be explained by the fact that AIREBO potential is not suitable for such simulations. Atoms in the basal plane cannot attach hydrogen atoms during simulation. Analysis of the structure during exposure at $300 \mathrm{~K}$ showed that most of the hydrogen atoms in the process of relaxation transform into the molecular state $\mathrm{H}_{2}$. At the same time, with an increase of the deformation value, number of $\mathrm{H}$ atoms (a curve with triangular symbols in Fig. 2) slightly increases from $28 \%$ to $32-33 \%$.

Based on the conducted analysis of the change in the concentration of hydrogen atoms in the structure of crumpled graphene, the dependence of the volumetric capacity of accumulated hydrogen $\rho_{V}$ on the degree of deformation $\varepsilon$, is presented in Fig. 3. It can be seen, that with an increase in the deformation value of crumpled graphene, a monotonic increase in $\rho_{V}$ occurs, and the slope of the curve $\rho_{V}(\varepsilon)$ decreases with deformation value increasing. Compressive strain above $25 \%$ is not considered because at this strain level structure density considerably increased and hydrogen atoms attached to graphene surface or free cannot be distinguished.

An important characteristic of carbon structures used for hydrogen storage and transportation is gravimetric capacity. Gravimetric capacity of crumpled graphene $\rho_{g}$ as the function of deformation $\varepsilon$ after exposure at $300 \mathrm{~K}$ is shown in Fig. 4. It can be seen that gravimeric capacity is not changing. As it is mentioned above, this is connected with the applied potential function.

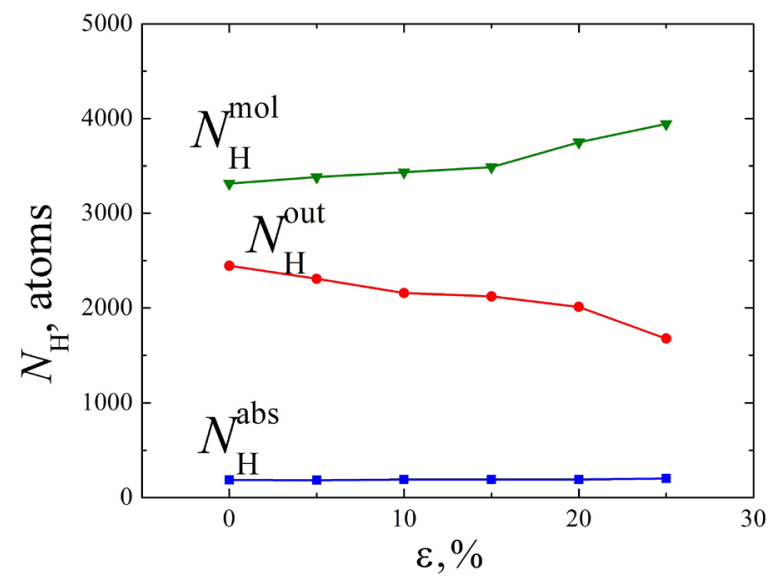

Fig. 2. Number of hydrogen atoms in crumpled graphene as the function of strain $\varepsilon$ after exposure at $300 \mathrm{~K}$ : curve with circles the amount of hydrogen that move out of the structure $N_{H}^{\text {out }}$; curve with squares - the amount of absorbed hydrogen $N_{H}^{a b s}$; curve with triangles - the amount of molecular hydrogen $N_{H}^{\text {mol }}$.

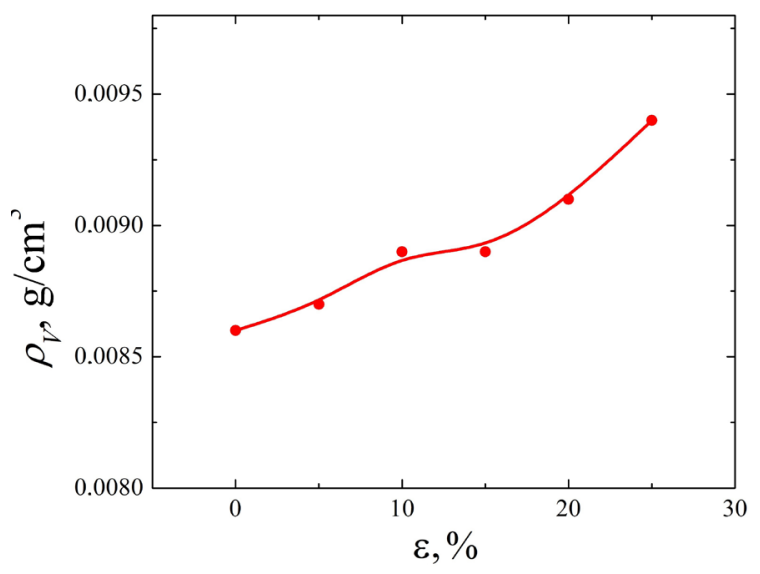

Fig. 3. Volumetric capacity of stored hydrogen $\rho_{V}$ as the function of strain $\varepsilon$ after exposure at $300 \mathrm{~K}$. 


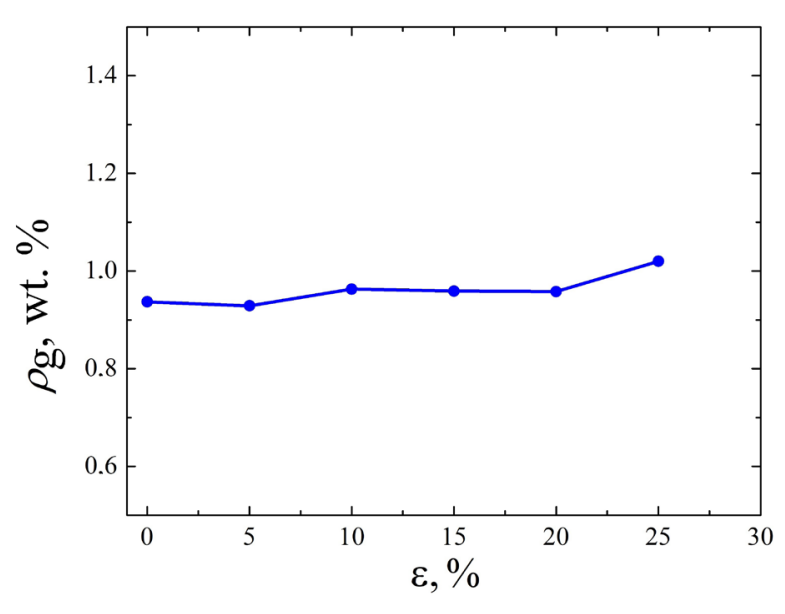

Fig. 4. Gravimetric capacity $\rho_{\mathrm{g}}$ of crumpled graphene as the function of strain $\varepsilon$ after exposure at $300 \mathrm{~K}$.

\section{Conclusions}

The results obtained by molecular dynamics simulation show that hydrostatic compression is an effective way to increase the volumetric capacity of hydrogen absorption by crumpled graphene. The number of hydrogen atoms moving from the pores of crumpled graphene during the simulation decreases noticeably with an increase in the compression value.

The data obtained allow to predict the possibility of using crumpled graphene as a medium for hydrogen storage and transportation. Hydrostatic compression of the structure leads to a significant increase in both the sorption capacity of graphene and the better preservation of hydrogen molecules in the pores and folds of graphene flakes. It is expected that the subsequent heating of the structure will lead to the full opening of graphene flakes and the release of hydrogen, which is important for dehydrogination mechanisms.

Acknowledgements. Work of J.A.B. (initial structures preparation) was supported by the grant of the President of the Russian Federation for state support of young Russian scientists - doctors of sciences MD-1651.2018.2. The work of K.A.K. (calculations of the hydrogen capacity) was partly supported by the State Assignment of IMSP RAS.

\section{References}

1. L. Yu. Antipina, P.V. Avramov, S. Sakai, H. Naramoto, M. Ohtomo, S. Entani, Y. Matsumoto, P. B. Sorokin. Phys. Rev. B. 86, 085435 (2012). DOI: 10.1103/PhysRevB.86.085435

2. L. Zhang, F. Zhang, X. Yang, G. Long, Y. Wu, T. Zhang, K. Leng, Y. Huang, Y. Ma, A. Yu, Y. Chen. Sci. Rep. 3, 1408 (2013). DOI: 10.1038/srep01408

3. J.A. Baimova, B. Liu, S.V. Dmitriev, K. Zhou. J. Phys. D: Appl. Phys. 48 (9), 095302 (2015). DOI: 10.1088/0022-3727/48/9/095302

4. Z. Tang, X. Li, T. Sun, S. Shen, J. Yang. Micropor. Mesopor. Mat. 272, 40 (2018). DOI: $10.1016 /$ j.micromeso.2018.06.020

5. A. Pedrielli, S. Taioli, G. Garberoglio, N.M. Pugno.
Micropor. Mesopor. Mat. 257, 222 DOI: 10.1016/j.micromeso.2017.08.034

(2018).

6. Y. Wang, Y. Zhu, F. Wang, X. Liu, H. Wu. Carbon. 118, 588 (2017). DOI: 10.1016/j.carbon.2017.03.092

7. L. A. Chernozatonsky, V.A. Demin. JETP Lett. 107 (5-6), 333 (2018). DOI: 10.7868/S0370274X18050107

8. N. Novikov, M. Maslov, K. Katin, V. Prudkovskiy. Letters on Materials. 7 (4), 433 (2017). DOI: 10.22226/2410-3535-2017-4-433-436

9. E.A. Belenkov, V.A. Greshnyakov. Physics of the Solid State. 57 (6), 1253 (2015). DOI: $10.1134 /$ S1063783415060049

10. E. A. Belenkov, V.A. Greshnyakov. Letters on Materials. 7 (3), 318 (2017). (in Russian) [Е.A. Беленков, B.A. Грешняков. Письма о материалах. 7 (3), 318 (2017).] DOI: $10.22226 / 2410-3535-2017-3-318-322$

11. K.A. Krylova, Y.A. Baimova, S.V. Dmitriev, R. R. Mulyukov. Physics of the Solid State. 58 (2), 394 (2016). DOI: 10.1134/S1063783416020189

12. V. V. Mavrinskii, E. A. Belenkov. Letters on Materials. 8 (2), 169 (2018). (in Russian) [В.В. Мавринский, E.A. Беленков. Письма о материалах. 8 (2), 169 (2018).] DOI: 10.22226/2410-3535-2018-2-169-173

13. D.S. Lisovenko, J.A. Baimova, L.Kh. Rysaeva, V.A. Gorodtsov, A.I. Rudskoy, S.V. Dmitriev. Phys. Status Solidi (b). 253 (7), 1295 (2016). DOI: $10.1002 /$ pssb.201600049

14. E. Poirier, R. Chaine, P. Bernard, D. Cossement, L. Lafi, E. Melanson, T. K. Bose, S. Desilets. Appl. Phys. A. 78, 961 (2004). DOI: 10.1007/s00339-003-2415-y

15. T. Heine, L. Zhechkov, G. Seiferta. Phys. Chem. Chem. Phys. 6, 980 (2004). DOI: 10.1039/B316209E

16. M. Marella, M. Tomaselli. Carbon. 44 (8), 1404 (2006). DOI: $10.1016 /$ j.carbon.2005.11.020

17. G.E. Froudakis. Mater. Today. 14 (7-8), 324 (2011). DOI: $10.1016 /$ S1369-7021(11)70162-6

18. Yu. S. Nechaev and N. T. Veziroglu. Int. J. Phys. Sci. 10 (2), 54 (2015). DOI: 10.5897/IJPS2014.4212

19. K.P. Katin, V.S. Prudkovskiy, M.M. Maslov. Phy. Lett. A. $381 \quad$ (33), $2686 \quad$ (2017). DOI: $10.1016 /$ j.physleta.2017.06.017

20. D. C. Elias, R. R. Nair, T. M. G. Mohiuddin, S. V. Morozov, P. Blake, M. P. Halsall et. al. Science. 323, 610 (2009). DOI: $10.1126 /$ science. 1167130

21. L. Zhang, X. Zeng, X. Wang. Sci. Rep. 3, 3162 (2013). DOI: $10.1038 /$ srep03162

22. S. Stuart, A. Tutein, J. Harrison, J. Chem. Phys. 112, 6472 (2000). DOI: 10.1063/1.481208

23. B. Liu, J.A. Baimova, S. V. Dmitriev, X. Wang, H. Zhu, K. Zhou, J. Phys. D 46 (30), 305302 (2013). DOI: $10.1088 / 0022-3727 / 46 / 30 / 305302$

24. J. A. Baimova, R. T. Murzaev, I. P. Lobzenko, S. V. Dmitriev, K. Zhou. Journal of Experimental and Theoretical Physics. 122 (5), 869 (2016). DOI: 10.1134/S1063776116040014

25. J.A. Baimova, R. T. Murzaev, A.I. Rudskoy. Phys. Lett. A. 381 (36), $3049 \quad$ (2017). DOI: $10.1016 /$ j.physleta.2017.07.027

26. Q.X. Pei, Y.W. Zhang, V. B. Shenoy. Carbon. 48 (3), 898 (2010). DOI: 10.1016/j.carbon.2009.11.014

27. N.-N. Li, Z.-D. Sha, Q.-X. Pei, Y.-W. Zhang. The Journal 
of Physical Chemistry C. 118 (25), 13769 (2014). DOI: $10.1021 /$ jp502084f

28. Z. Zhang, Y. Xie, Q. Peng, Y. Chen. Solid State Commun. 213 -214, 31 (2015). DOI: 10.1016/j.ssc.2015.04.014

29. C. Li, G. Li, H. Zhao. Carbon. 72, 185 (2014). DOI: $10.1016 /$ j.carbon.2013.09.080

30. A. Montazeri, S. Ebrahimi, H. Rafii-Tabar. Molecular Simulation. 41 (14), $1212 \quad$ (2014). DOI: 10.1080/08927022.2014.968849

31. J. A. Baimova, B. Liu, S. V. Dmitriev, K. Zhou. Phys. Status Solidi (RRL). 8 (4), 336 (2014). DOI: 10.1002 /pssr.201409063

32. J.A. Baimova, R.T. Murzaev, S.V. Dmitriev. Physics of the Solid State. 56 (10) 2010 (2014).
DOI: $10.1134 / \mathrm{S} 1063783414100035$

33. J.A. Baimova, B. Liu, S.V. Dmitriev, N. Srikanth, K. Zhou. Phys. Chem. Chem. Phys. 16, 19505 (2014). DOI: $10.1039 / \mathrm{c} 4 \mathrm{cp} 01952 \mathrm{k}$

34. Z. Sun, D. K. James, J. M. Tour, J. Phys. Chem. Lett. 2011, 2, 2425 - 2432. DOI: 10.1021/jz201000a

35. A. V. Savin, Y.S. Kivshar. Europhys. Lett. 2010, 89, 46001. DOI: 10.1209/0295-5075/89/46001

36. X. Gao, Y. Wang, X. Liu, T.-L. Chan, S. Irle, Y. Zhao, S. B. Zhang. Phys. Chem. Chem. Phys. 13, 19449 (2011). DOI: $10.1039 / \mathrm{clcp} 22491 \mathrm{c}$

37. V.D. Camiola, R. Farchioni, T. Cavallucci, A. Rossi, V. Pellegrini, V. Tozzini. Frontiers in Materials. 2, 3 (2015). DOI: $10.3389 /$ fmats.2015.00003 